\title{
The protective role of zinc in the toxic action of coal dust upon mouse macrophages
}

\author{
Yu-rong Lai, Jin-liang Chen, Xiu-yun Jiang, Guang-kai Yang, Si-qin Yang, Wen-xian Gao
}

\begin{abstract}
Macrophages from mice were cultured at $37^{\circ} \mathrm{C}$ with 1640 medium containing $10 \%$ bovine serum. The macrophage suspension was made from 50 Swiss mice and was cultured in the following groups: control group; coal dust group (with added coal dust particles $(10 \mu \mathrm{g} /$ ml) smaller than $4 \mu \mathrm{m}$ diameter); subdivided zinc-coal dust group (as coal dust group with zinc added in three different concentrationsnamely, $10 \mathrm{ppm}, 30 \mathrm{ppm}$, and $60 \mathrm{ppm}$ ). Cells were examined by light microscopy. Obvious differences were found in the rate of cell deaths between the coal dust group and the zinc-coal dust group after culture for $\mathbf{4 8}$ hours. The cell membranes were ruptured after culturing with coal dust, and the presence of zinc appeared in some degree to protect cell membranes from damage caused by the dust. Staining the cells with Gomori's modified method, showed that acid phosphatase particles in the zinc-coal dust group were more numerous than in the coal dust group. The results indicate that the trace element zinc may play an important part in protecting against the cytotoxic action of coal dust.
\end{abstract}

Death and disruption of pulmonary macrophages may play a part in the development of pneumoconiosis. ${ }^{1}$ The trace element zinc can affect the activities of many enzymes in the human body. Evidence has been presented to show that zinc and other trace elements have an important influence in the development of pneumoconiosis. ${ }^{23}$ Changes in morphology and cytochemistry of mouse macrophages after culturing were the basis for our study of the protective effect of zinc upon the toxic action of coal dust.

Department of Public Health, Fujian Medical College, Fuzhou 35004, Peoples' Republic of China Y-r Lai

Fujian Provincial Hygiene and Anti-epidemic Station

J-1 Chen, X-y Jiang, S-q Yang, W-x Gao

Fujian Provincial Coal Miners' Sanatorium G-k Yang

\section{Materials and methods}

We prepared a mouse macrophage suspension by the method of Wasley. ${ }^{4}$ The cell suspension was made from 25 male and 25 female Swiss mice weighing 18$25 \mathrm{~g}$. The suspension was put into culture tubes containing small slips of glass. The cells adhered to the glass and were counted and washed with Hanks solution ( $\mathrm{pH} \mathrm{7.8;} \mathrm{Fujian} \mathrm{provincial} \mathrm{hygiene} \mathrm{and} \mathrm{anti-}$ epidemic station cell laboratory). Finally, the macrophages were statically cultured at $37^{\circ} \mathrm{C}$ with 1640 medium (GIB Co, USA) containing $10 \%$ bovine serum.

After four hours of culture, the macrophages were divided into groups, fourteen tubes in each group, as follows: (1) control group cultured only with 1640 medium containing $10 \%$ bovine serum; (2) coal dust group; coal dust particles smaller than $4 \mu \mathrm{m}$ diameter and containing $8 \cdot 1 \%$ quartz were added to the culture fluid to a concentration of $10 \mu \mathrm{g} / \mathrm{ml}$; (3) zinccoal dust group; zinc and coal dust were put into the culture fluid together. This group was subdivided into three (14 tubes in each subgroup), the presence of zine ions being at concentrations of $10 \mathrm{ppm}$, $30 \mathrm{ppm}$, and $60 \mathrm{ppm}$ in the three subgroups. The concentration of coal dust was $10 \mu \mathrm{g} / \mathrm{ml}$ throughout.

The macrophages were examined by light microscopy at two, four, six, eight, 12, 24, and 48 hours of culture.

Coverslip cultures were taken out at appropriate times, washed with Hanks solution, then stained with trypan blue to determine the rate of survival of the cells. Morphological changes in the cells were also studied.

The macrophage cultures were also stained using Gomori's modified staining procedure for acid phosphatase (ACP). ${ }^{5}$ The ACP activities were qualitatively recorded as,+++++ , or + , according to the number of ACP particles in macrophages.

The viability count of cells after different periods in culture was measured in 10 fields of vision by one person. The mean of five counts was taken as the rate of survival. Differences between groups were analysed by $\chi^{2}$ test.

\section{Results} MORPHOLOGY

Control group -During the period of culture most of 
the macrophages were circular or showed extended processes. Particles of ACP were distributed evenly or concentrated at the sides of the cells. The cell membranes were intact.

Coal dust group-After a culture period of 12 hours the macrophages were enlarged and had more projections. The cells were polygonal or spindle shaped. Many coal dust particles were engulfed by macrophages. The cell membranes were not always intact and some of the macrophages had died. Particles of ACP were rare with most of the ACP scores recorded as + .

Zinc-coal dust group-After phagocytosing zinc treated coal dust particles the cells were enlarged and circular but fewer dust particles were engulfed than in the coal dust group. Most cell membranes were intact. At a later stage of culture particles of ACP could still be clearly seen in the macrophages especially in the group with a concentration of zinc of $60 \mathrm{ppm}$.

\section{MACROPHAGE CYTOTOXICITY}

The number of cells dying in the coal dust group had increased rapidly by six hours after culture. By contrast, the number of dead cells in the zinc-coal dust group increased more slowly than in the coal dust group. No significant differences were found ( $p>0.05$ ) between the control group and the zinccoal dust subgroup in which the concentration of zinc was $60 \mathrm{ppm}$ (table 1 ).

\section{ACID PHOSPHATASE STAINING}

Table 2 shows the variation in qualitative scores of ACP. In general the ACP scores in the groups decreased with time of culture. The ACP particles in the coal dust group, however, decreased more than in the other groups, or disappeared altogether. At the later culture periods, ACP particles were still located in the macrophages of the zinc-coal dust group with more ACP particles recorded +++ in the zinc-coal dust group than in the coal dust group.

\section{Discussion}

Regarding the protective role of zinc in the toxic action of coal dust, Sorenson et al $^{6}$ and Christian et $a l^{7}$ studied metal elements in two collieries with differences in the incidence of pneumoconiosis and showed that various metal elements in coal dust related closely to the toxic action of the dust. In the colliery with higher zinc concentrations in coal dust

Table 1 Percentage of macrophage deaths at different culture times

\begin{tabular}{|c|c|c|c|c|c|}
\hline \multirow[b]{2}{*}{$\begin{array}{l}\text { Hours of } \\
\text { culture }\end{array}$} & \multirow[b]{2}{*}{$\begin{array}{l}\text { Control } \\
\text { group }\end{array}$} & \multirow[b]{2}{*}{$\begin{array}{l}\text { Coal dust } \\
\text { group }\end{array}$} & \multicolumn{3}{|c|}{ Zinc-coal dust group } \\
\hline & & & $\begin{array}{l}10 \text { ppm } \\
\text { zinc }\end{array}$ & $\begin{array}{l}30 \text { ppm } \\
\text { zinc }\end{array}$ & $\begin{array}{l}60 \text { ppm } \\
\text { zinc }\end{array}$ \\
\hline $\begin{array}{r}2 \\
4 \\
6 \\
8 \\
12 \\
24 \\
48\end{array}$ & $\begin{array}{r}1 \cdot 41 \\
5 \cdot 64 \\
7 \cdot 57 \\
17 \cdot 42 \\
18 \cdot 25 \\
21 \cdot 47 \\
25 \cdot 75\end{array}$ & $\begin{array}{r}2 \cdot 86 \\
5 \cdot 20 \\
28 \cdot 05 \\
40 \cdot 41 \\
44 \cdot 26 \\
40 \cdot 93 \\
92 \cdot 30\end{array}$ & $\begin{array}{r}2.43 \\
5.62 \\
9.90 \\
19.58 \\
24.97 \\
26.82 \\
46.68\end{array}$ & $\begin{array}{r}1.56 \\
4.04 \\
7 \cdot 71 \\
12 \cdot 04 \\
14 \cdot 25 \\
16 \cdot 56 \\
32 \cdot 23\end{array}$ & $\begin{array}{r}1.82 \\
3.92 \\
7.22 \\
13.93 \\
12.06 \\
20.90 \\
27.68\end{array}$ \\
\hline p Value ${ }^{\star}$ & & $<0.01$ & $<0.01$ & $<0.05$ & $>0.05$ \\
\hline
\end{tabular}

*Compared with the control group. Numbers are means of 14 .

Table 2 Change in \% of cells within qualitative scoring groups for ACP particles

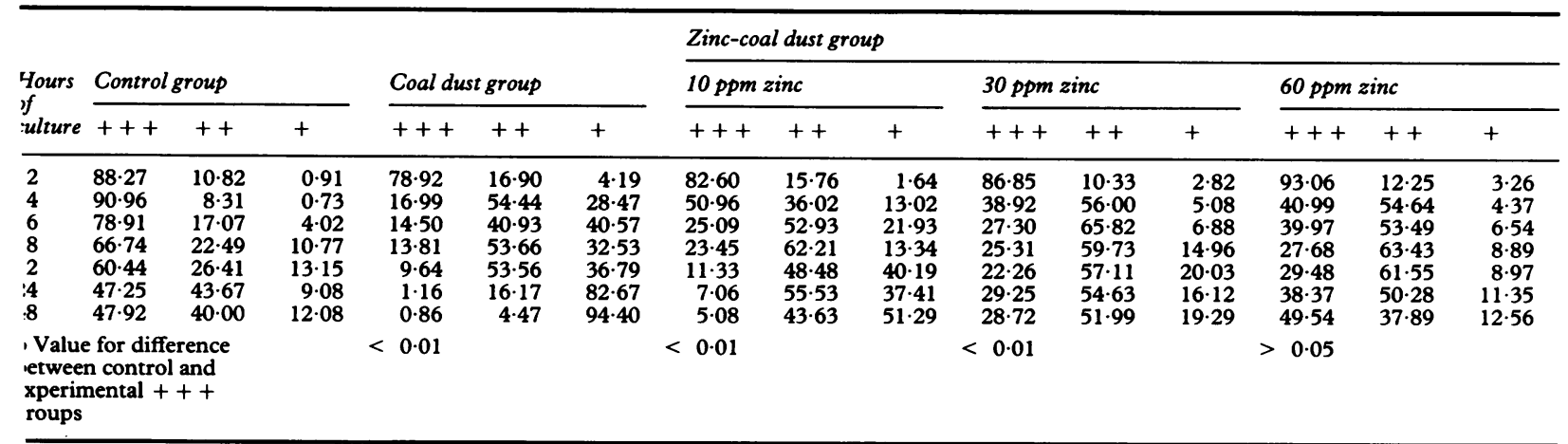

ACP particles that are marked +++ compared with control group. 
the incidence of pneumoconiosis was lower. Zhang et $a l^{8}$ studied the relation between metal elements and the toxicity of coal dust. Their results showed that the cytotoxicity of various coal dusts was not completely in keeping with the concentration of free silica, and the metal elements in various coal dusts appeared to have some effect upon cytotoxicity. The lowest toxic action of coal dust was found when the concentration of zinc was high, the rate of survival of the cells and the preservation of lysosome membranes being greater than with other metals. In the present study zinc appeared to protect the macrophages from coal dust mediated damage to some degree as measured by more intact cell structures, decreased phagocytosis, and increased survival of the macrophages with sustained ACP activity. A dose dependent protective action of zinc in the culture liquid was evident. In the $30 \mathrm{ppm}$ group (the average concentration of zinc found in the human body ${ }^{9}$ ) the protective action of zinc was substantial and in the 60 ppm group the protective action was even more obvious. These results are similar to those in the studies mentioned above and suggest a potentially important role for zinc in workers who are in contact with coal dust.

Zinc can apparently restrain the phagocytic function of macrophages and protect the cell membrane from damage. After coal dust is added to the culture liquid, macrophages are normally stimulated to phagocytose a large amount of dust. The dust in the macrophage then damages the cell membranes and causes cell lysis. The presence of zinc, however, limits the degree of damage to the cell membrane by limiting phagocytosis. With the raising of zinc concentration, its protective action becomes stronger. This finding agrees with that reported by Smith $e t$ $a l^{10}$ who indicated that zinc can inhibit lipid peroxidation and stabilise cell membrane structure and function.

The concentration of zinc in the human body has been reported to have a relation with the occurrence and development of pneumoconiosis. Thus blood or lung zinc concentrations in patients with pneumoconiosis were lower than those in controls suggesting that the controls were protected. ${ }^{11}{ }^{12}$ In the process of development of pneumoconiosis, phagocytosis and subsequent damage to the macrophage is considered to be one of the important steps. ${ }^{1}$ Heppleston and Styles ${ }^{13}$ reported that silica activated macrophages produced a factor that enhanced the synthesis of collagenous hydroxyproline by fibroblasts. Chvapil ${ }^{3}$ pointed out that zinc might both inhibit the phagocytic function of the macrophage and have other functions. He supplied zinc to reduce exposed to silica laden dust; simultaneously the synthesis of collagen was reduced by $45 \%$. In the present study in the low zinc concentration group $(10 \mathrm{ppm})$ the protective effect on the macrophage was not strong but in the high zinc concentration groups (30 ppm and $60 \mathrm{ppm}$ ) the protective actions of zinc were remarkable. When dust is inhaled, the macrophages may be stimulated to increase secretion of leucocyte endogenous mediator, ${ }^{14}$ which may enhance the synthesis of fibrin and $\alpha 1$ phosphoric acid glycoprotein. This exhausts zinc rapidly and induces low blood zinc concentrations, which may result in a vicious circle of macrophage damage. If zinc can be supplied in time the early development of pneumoconiosis may be averted but further experiments are necessary before this can be confirmed, and the possibility of toxic effects of added zinc must be ruled out.

1 Allison AC, Harington JS, Birbeck M. An examination of the cytotoxic effects of silica on macrophages. J Exp Med 1966;124:141-53.

2 Niculescu T, Dumitru R, Burnea D. Changes of copper, iron and zinc in the serum of patients with silicosis, silicotuberculosis and active lung tuberculosis. Environmental Research 1981; 25:260-8.

3 Chvapil M. New aspects in the biological role of zinc: a stabilizeo of macromolecules and biological membranes. Life Sci 1973 13:1041-9.

4 Wasley GD. Animal tissue culture: advances in technique London: Butterworths, 1972:128-32.

5 Pearse AGE. Histochemistry theoretical and applied. 2nd ed. London: Churchill, 1960:431-53.

6 Sorenson JRJ, Kober T, Petering $\mathrm{H}$. The concentration of $\mathrm{Cd}$ $\mathrm{Cu}, \mathrm{Fe}, \mathrm{Ni}, \mathrm{Pb}$, and $\mathrm{Zn}$ in bituminous coals from mines with differing incidence of coal workers' pneumoconiosis. Am Ind Hyg Assoc J 1974;35:93-8.

7 Christian RT, Nelson JB, Cody TE, Larson E, Bingham E. Coa workers' pneumoconiosis: in vitro study of the chemical composition and particle size as causes of the toxic effects of coal. Environ Res 1979;20:358-65.

8 Zhang Qi-feng, Yang Sai-li, Zhang Xi-ze, Sa Yun. Study on relationship of cytotoxicity and metal elements of coal dusts in various coal mines. Chinese Journal of Industrial Hygiene and Occupational Diseases 1987;13:284-7. (In Chinese.)

9 Schroedor HA. The trace elements and man. New York: The Devin-Adair Co, 1973:23-39.

10 Smith JE, Brown ED, Smith JC. The effect of zinc deficiency on the metabolism of retinal-binding protein in the rat. J Lab Clin Med 1974;84:692-7.

11 Chai Gu-pen, Xu Bo-huong, Yin Tai-an, Li Yu-lai. Changes of copper and zinc in serum and lung in mice pneumoconiosis. Journal of Institute of Health 1984;13:1 1-4. (In Chinese.)

12 Zhou Ji-gui, Shao Zhou-fei, Li Chang-chun, Zhao Chun-xiu, Li Yu-ming. Clinical significance of the determination of serum $\mathrm{Zn}$ and $\mathrm{Cu}$ in coal workers' pneumoconiosis. Journal of Clinical Medicine 1987;3:187-8. (In Chinese.)

13 Heppleston AG, Styles JA. Activity of a macrophage factor in collagen formation by silica. Nature 1967;214:521-6.

14 Pekarek RS, Wannemacher RW Jr, Beiael WR. The effect of leukocytic endogenous mediator (LEM) on the tissue distribution of zinc and iron. Proc Soc Exp Biol Med 1972, 140:685-7.

Accepted 8 April 1991 